Al-Kimia, 8-1-2020, 72-82

Available online at: http://journal.uin-alauddin.ac.id/index.php/al-kimia

\title{
Aktivitas Antibakteri Turunan Kalkon Tersubstitusi Bromo Terhadap Bakteri Bacillus subtilis dan Escherichia coli
}

\author{
Retno Aliyatul Fikroh*, Sabirin Matsjeh, dan Cahiril Anwar \\ Program Studi Pendidikan Kimia, Fakultas Sains dan Teknologi, UIN Sunan Kalijaga, \\ Yogyakarta, Indonesia \\ *Corresponding Author: aliyafikroh1992@gmail.com
}

Received: January,20,2020 /Accepted: June,29,2020 doi: 10.24252/al-kimiav8i1.12024

\begin{abstract}
Pengembangan obat antibiotik dalam menanggulangi penyakit akibat infeksi bakteri semakin meluas. Hal ini diiringi dengan semakin meningkatnya prevalensi retensi terhadap antibiotik. Banyaknya kasus retensi terhadap antibiotik menyebabkan perlu dilakukan pengembangan agen antibakteri yang salah satunya berasal dari senyawa turunan kalkon. Sintesis senyawa turunan kalkon yang memiliki aktivitas dalam menghambat bakteri Bacillus subtilis dan Escerichia coli telah dilakukan. Sintesis senyawa (E)-2'-hidroksi-2-bromo-4,5-dimetoksikalkon melalui reaksi kondensasi Claisen-Schmidt dari senyawa 2-hidroksiasetofenon dengan 2-bromo4,5-dimetoksibenzaldehida. Sintesis dilakukan dengan metode refluks dalam kondisi basa menggunakan katalis $\mathrm{NaOH}$ dan metanol sebagai pelarut selama 24 jam. Struktur hasil sintesis senyawa turunan kalkon dianalisis dengan FTIR, KLT-scanner, GC-MS, MS-direct, ${ }^{l} H$-NMR dan ${ }^{13} \mathrm{C}-\mathrm{NMR}$. Uji antibakteri dilakukan dengan metode difusi cakram (sumuran) terhadap bakteri Bacillus subtilis dan Escherichia coli. Seri konsentrasi senyawa meliputi 1\%, 5\%, 10\%, dan $20 \%$ serta digunakan kontrol positif 4-isopropil-3-metilfenol 1\%. Hasil penelitian menunjukkan bahwa sintesis senyawa turunan kalkon menghasilkan padatan berwarna kuning dengan rendemen sebesar 78,45\%. Daya hambat senyawa kalkon dan 4-isopropil-3-metilfenol sebagai kontrol positif hampir sama untuk kedua bakteri yaitu $15 \mathrm{~mm}$ untuk Bacillus substilis dan $13 \mathrm{~mm}$ untuk Escherichia coli. Selain itu, uji daya hambat senyawa turunan kalkon terhadap bakteri Bacillus substillis lebih baik dibandingkan pada bakteri Escherichia coli pada konsentrasi $20 \%$ dengan zona hambat berturutturut sebesar 19,7 dan 17,7 $\mathrm{nm}$.
\end{abstract}

Key word: sintesis, turunan kalkon, antibakteri

\section{PENDAHULUAN}

Penggunaan antibiotik menjadi penting dalam memerangi penyakit menular yang disebabkan oleh bakteri dan mikroba lainnya sejak ditemukannya penisilin sebagai antibakteri yang kuat. Akan tetapi, penggunaan antibiotik secara luas telah mengakibatkan munculnya patogen yang resisten terhadap antibiotik (Normark dkk., 2002). Munculnya spesies bakteri yang lebih patogen terhadap antibiotik telah meningkatkan biaya produksi bahkan kegagalan dalam pengobatan penyakit. World Health Organization (WHO) pada tahun 2014 telah melakukan pendataan terhadap resistensi bakteri untuk berbagai wilayah di dunia antaranya Afrika, Amerika, Eropa, dan Asia dengan data yang menyatakan sebagian besar jenis bakteri yang resisten antara lain Escherichia coli dan Staphylococcus aureus. Hal ini disebabkan karena bakteri mempunyai kemampuan beradaptasi terhadap senyawa antibakteri sehingga terjadi penghambatan kerja dari antibakteri tersebut.

Kemampuan retensi bakteri terhadap antibiotik dapat diatasi dengan melakukan regenerasi senyawa antibakteri dengan mengganti sisi aktif dari senyawa antibakteri sehingga terjadi perubahan reseptor pada bakteri. Penambahan substituen yang bersifat farmakofor pada struktur senyawa antibakteri dapat meningkatkan aktivitas antibakteri (Nugraha, 2015). Dengan munculnya mikroba baru yang resisten terhadap antibiotik yang tersedia, maka minat penemuan agen antibakteri baru semakin meningkat. Metode 
pengembangan obat yang populer saat ini dengan melakukan studi hubungan kuantitatif struktur aktivitas dengan mempelajari struktur induk suatu senyawa kemudian menghasilkan derivatnya dan membandingkan aktivitas farmakologisnya.

Salah stau golongan flavonoid dari jenis kalkon memiliki potensi sebegai antibiotik. Turunan kalkon telah banyak dilaporkan memiliki aktivitas biologis dan farmakologis yang bervariasi. Kalkon sebagai metabolit sekunder dikenal memiliki aktivitas biologi sebagai antikanker (Achanta dkk., 2006), antiinflamasi (Kim dkk., 2007), anti-aids (Wu dkk., 2003) dan antimikroba (Bhuiyan, 2011). Menurut Lahtchev dkk (2008) karakteristik antibakteri pada senyawa kalkon juga bergantung pada substituen yang terikat di kedua cincin aromatiknya. Gugus halogen seperti $\mathrm{Cl}$ dan $\mathrm{Br}$ dikenal memiliki aktivitas antibakteri yang cukup baik (Prasad dkk., 2006). Kalkon yang tersubstitusi halogen tidak ditemukan di alam sehingga untuk mendapatkannya diperlukan cara sintesis. Oleh karena itu, penelitian ini bertujuan untuk mensintesis senyawa turunan kalkon yang tersubstitusi gugus halogen yaitu bromo serta melakukan uji aktivitas terhadap bakteri Bacillus subtilis dan Escherichia coli.

\section{METODE PENELITIAN}

\section{Alat dan Bahan}

Bahan yang digunakan dalam penelitian ini memiliki kualitas pro analisis dari Merck antara lain 3,4-dimetoksibenzaldehida, 2-hidroksiasetofenon, natrium hidroksida, metanol, etanol, asam klorida, asam asetat glasial, asam bromida, n-heksana, etil asetat dan aquades. Bahan dengan kualitas pro analisis dari Sigma Aldrich antara lain kalium bromat dan natrium tiosulfat. Bahan yang digunakan untuk uji bakteri antara lain bakteri Escherichia coli, Bacillus substilis, nutrien agar steril, kloramfenikol (p.a) dimetilsulfoksida, yang diperoleh dari laboratorium mikrobiologi Fakultas Kedokteran Hewan UGM Yogyakarta.

Alat-alat yang digunakan dalam penelitian ini adalah seperangkat alat refluks (pyrex), melting point apparatus, Fourier Transform Infrared (FTIR, Shimadzu Prestige 21), Gas Chromatography-Mass Spectrometry (GC-MS, Shimadzu QP 2010S), MS-direct, KLT scanner, Proton Nuclear Magnetic Resonance Spectroscopy $\left({ }^{1} \mathrm{H}-\mathrm{NMR}, 500 \mathrm{MHz}\right)$, Carbon Nuclear Magnetic Resonance Spectroscopy $\left({ }^{13} \mathrm{C}-\mathrm{NMR}, 125 \mathrm{Mhz}\right)$ menggunakan standar internal TMS dalam pelarut DMSO dan $\mathrm{CDCl}_{3}$. Alat yang digunakan dalam uji antibakteri antara lain cawan petri, tabung reaksi, kompor listrik, vorteks, ring sumuran, autoklaf, mikropipet, oven, laminar air flow, dan timbangan elektrik.

\section{Instrumentasi \\ Prosedur \\ Sintesis 2-bromo-4,5-dimetoksibenzaldehida}

Kalium bromat (4,8 mmol), asam asetat (20 ml) dan 3,4-dimetoksibenzaldehida (12 mmol) dimasukkan dalam erlenmeyer yang dilengkapi pengaduk magnet. Campuran diaduk hingga homogen selanjutnya ditambahkan asam bromida $(47 \%, 4 \mathrm{~mL})$ secara tetestetes hingga berwarna merah kecoklatan. Pengadukan dilakukan selama 1 jam pada suhu ruang. Ditambahkan $50 \mathrm{~mL}$ aquades dan dilanjutkan pengadukan selama 10 menit. Ke dalam campuran ditambahkan larutan natrium tiosulfat $(10 \%, \mathrm{~b} / \mathrm{v})$ hingga berubah warna menjadi abu-abu. Endapan yang terbentuk disaring dan dicuci dengan akuades dingin. Padatan direkristalisasi dengan etanol panas (50\%) kemudian disaring dan dicuci dengan akuades dingin. Padatan dikeringkan, diuji titik leleh dan dikarakterisasi dengan FTIR, GCMS, dan ${ }^{1} \mathrm{HNMR}$. 


\section{Sintesis (E)-2'-hidroksi-2-bromo-4,5-dimetoksikalkon}

Senyawa 2-bromo-4,5-dimetoksibenzaldehida $(5 \mathrm{mmol})$ dilarutkan dalam metanol $(20 \mathrm{~mL})$ dengan pemanasan hingga larut. Senyawa 2-hidroksiasetofenon $(5 \mathrm{mmol})$ yang telah direaksikan dengan $\mathrm{NaOH}(40 \%, 12 \mathrm{~mL})$ ditambahkan dalam larutan 2-bromo-4,5dimetoksibenzaldehida. Campuran direfluks $\left(68^{\circ} \mathrm{C}\right)$ selama 24 jam dan dikotrol dengan KLT. Hasil refluks dituang dalam es akuades dan diasamkan dengan $\mathrm{HCl}(10 \%$, v/v) hingga terbentuk endapan. Endapan disaring dan direkristalisasi dengan etanol. Endapan hasil rekristalisasi dikeringkan dan dikarakterisasi dengan FTIR, TLC-scanner, MS-direct, ${ }^{1} \mathrm{H}$ NMR dan ${ }^{13} \mathrm{C}-\mathrm{NMR}$.

\section{Uji Aktivitas Antibakteri}

Lima buah Erlenmeyer $100 \mathrm{~mL}$ masing-masing dimasukkan 0,4 gram nutrient broth dan 0,8 gram agar yang dilarutkan kedalam akuades sebanyak $50 \mathrm{~mL}$. Larutan dipanaskan hingga nutrient broth dan agar larut secara sempurna. Larutan disterilisasi menggunakan autoklaf pada suhu $121^{\circ} \mathrm{C}$ dengan tekanan 15 psi selama 15 menit. Larutan didinginkan di dalam lemari pendingin selama 20 jam. Media yang didinginkan selanjutnya dipanaskan kembali hingga encer dan didiamkan beberapa saat hingga tidak terlalu panas. Setiap erlenmeyer diisi dengan $500 \mu \mathrm{L}$ bakteri patogen yaitu Bacillus subtillis dan Escherechia coli hasil peremajaan.

Larutan agar dituang ke dalam 5 buah cawan petri. Setelah media memadat kertas cakram yang telah ditetesi sampel uji dengan konsentrasi 1\%, 5\%, 10\%, dan 20\% (dalam pelarut DMSO) diletakkan diatas agar media. Kontrol positif yang digunakan yaitu 4isopropil-3-metildenol (O-cymen) 1\%. Masa inkubasi dilakukan selama 24 jam pada suhu $37^{\circ} \mathrm{C}$ yang selanjutnya dilakukan pengukuran zona hambat. Zona hambat diukur untuk menentukan aktivitas antimikroba dari senyawa turunan kalkon yang disintesis dan efektivitas terhadap kedua bakteri tersebut.

\section{HASIL DAN PEMBAHASAN}

\section{Sintesis 2-bromo-4,5-dimetoksibenzaldehida}

Sintesis senyawa 2-bromo-4,5-dimetoksibenzaldehida diperoleh dari brominasi senyawa 3,4-dimetoksibenzaldehida menggunakan asam bromida dengan katalis asam $\mathrm{KBrO}_{3}$ menghasilkan rendemen sebesar $75 \%$ dengan titik leleh $145^{\circ} \mathrm{C}$. Hasil spektra FTIR menunjukkan perubahan serapan vibrasi yang sebelumnya pada senyawa 3,4dimetoksibenzaldehida sebesar $1674 \mathrm{~cm}^{-1}$ bergeser menjadi $1666 \mathrm{~cm}^{-1}$ setelah dilakukan brominasi. Adanya puncak baru pada bilangan gelombang $655 \mathrm{~cm}^{-1}$ yang meruapkan vibrasi ulur dari $\mathrm{C}-\mathrm{Br}$ memperkuat bahwa brominasi telah terbentuk. Puncak serapan pada bilangan gelombang $2777 \mathrm{~cm}^{-1}$ sebagai serapan $\mathrm{C}-\mathrm{H}$ aldehida dan serapan $\mathrm{C}=\mathrm{C}$ aromatis ditunjukkan pada bilangan gelombang 1589 dan $1442 \mathrm{~cm}^{-1}$. Spektra FTIR hasil sintesis senyawa 2-bromo-4,5-dimetoksibenzaldehida ditunjukkan pada gambar berikut. 


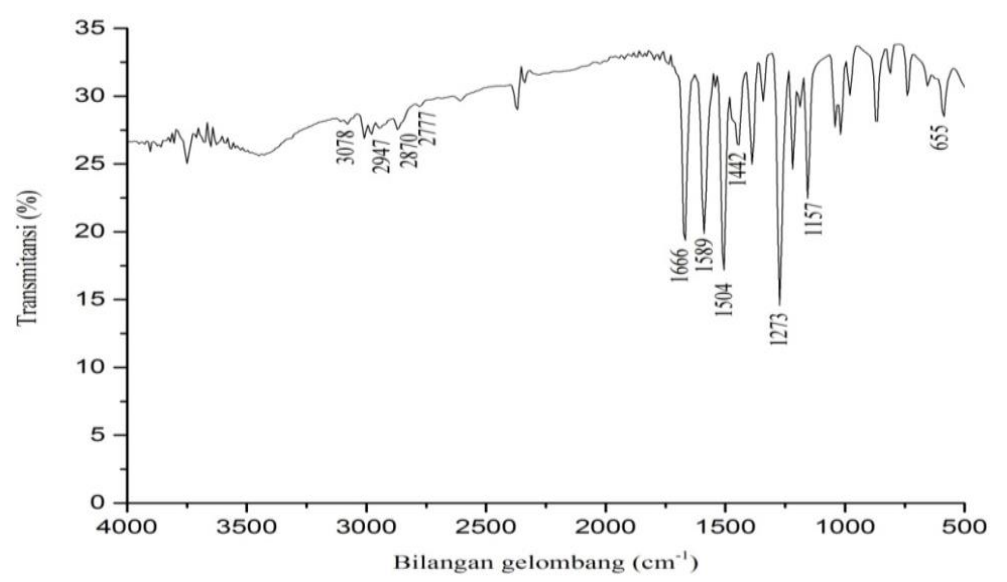

Gambar 1. Spektra FTIR senyawa 2-bromo-4,5-dimetoksibenzaldehida

Hasil GC menunjukkan bahwa senyawa hasil sintesis memiliki kemurnian sebesar $82 \%$. Hasil spektra massa menunjukkan berat molekul sesuai dengan senyawa target dimana ion molekuler $(\mathrm{M}+)$ sebesar 244 dan 246 dengan kelimpahan relatif sebesar 50,52\% dan 49,48\%. Berdasarkan analisis GC-MS menunjukkan indikasi terbentuknya senyawa 2bromo-4,5-dimetoksibenzaldehida dari reaksi brominasi 3,4-dimetoksibenzaldehida dengan produk yang cukup murni untuk dilanjutkan ke sintesis senyawa kalkon.

Hasil analisis ${ }^{1} \mathrm{H}-\mathrm{NMR}$ menunjukkan adanya 5 tipe proton yang berbeda sesuai dengan senyawa 2-bromo-4,5-dimetoksibenzaldehida. Hasil analisis ${ }^{1} \mathrm{H}-\mathrm{NMR}$ senyawa 2bromo-4,5-dimetoksibenzaldehida ditunjukkan pada gambar berikut.

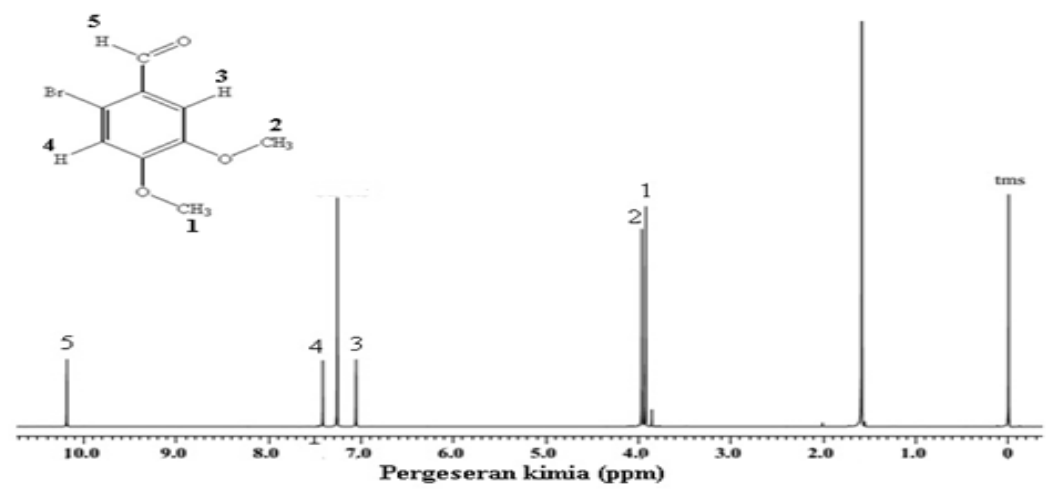

Gambar 2. Spektra ${ }^{1} \mathrm{H}-\mathrm{NMR}$ senyawa 2-bromo-4,5-dimetoksibenzaldehida

Puncak 1 dan 2 dengan pergeseran kimia $(\delta)$ pada 3,92 ppm dan 3,96 ppm memiliki kenampakan singlet yang masing-masing terintegrasi pada serapan proton gugus metoksi. Puncak 3 dan 4 dengan pergeseran kimia $(\delta)$ pada 7,05 ppm dan 7,41 ppm memiliki kenampakan singlet dengan karakteristik proton pada senyawa aromatis. Puncak 5 dengan pergeseran kimia $(\delta)$ pada 10,18 ppm merupakan serapan proton pada aldehida dengan kenampakan singlet.

Brominasi pada 3,4-dimetoksibenzaldehida memiliki kemungkinan terikat pada 3 posisi karbon pada senyawa aromatis yaitu pada posisi C-2, C-5 atau C-6. Puncak 3 dan 4 pada ${ }^{1} \mathrm{H}-\mathrm{NMR}$ menunjukkan kenampakan singlet yang berarti tidak terjadi splitting pada puncak tersebut. Hal ini menunjukkan bahwa posisi kedua proton terletak cukup jauh dan 
tidak saling mempengaruhi sehingga nilai tetapan kopling $(\mathrm{J})$ yang dianggap nil menunjukkan bahwa kedua proton tersebut berposisi para (Silverstein dkk., 2005).

Proses substitusi elektrofilik pada reaksi brominasi senyawa 3,4dimetoksibenzaldehida diperngaruhi oleh substituen pada senyawa tersebut. Gugus aldehida sebagai gugus pendeaktif mengarahkan bromo pada C-5. Gugus metoksi sebagai gugus pengaktivasi lebih mendominasi pengarahan gugus bromo pada C-2 atau C-6. Posisi C-2 bersifat sterik yang terlalu besar akibat diapit oleh gugus aldehid dan metoksi sehingga gugus bromo tersubstitusi pada C-6. Berdasarkan hal tersebut dapat disimpulkan bahwa gugus bromo tersubstitusi pada posisi 6 dari senyawa 3,4-dimetoksibenzaldehida menghasilkan senyawa 2-bromo-4,5-dimetoksibenzaldehida.<smiles>COc1ccc(C=O)cc1Br</smiles>

Gambar 3. Persamaan reaksi sintesis senyawa 2-bromo-4,5-dimetoksibenzaldehida.

\section{Sintesis (E)-2'-hidroksi-2-bromo-4,5-dimetoksikalkon}

Reaksi kondensasi Claisen-Schmidt antara senyawa 2-bromo-4,5dimetoksibenzaldehida dengan 2-hidroksiasetofenon menghasilkan (E)-2'-hidroksi-2bromo-4,5-dimetoksikalkon telah dilakukan. Turunan kalkon direfluks pada kondisi basa menggunakan katalis $\mathrm{NaOH}$ dalam pelarut metanol selama 24 jam. Produk yang dihasilkan berbentuk padatan berwarna kuning dengan rendemen sebesar 78,45\% dan titik leleh sekitar $169-170^{\circ} \mathrm{C}$.<smiles>COc1cc(Br)c(/C=C/C(=O)c2ccccc2O)cc1OC</smiles>

Gambar 4. Persamaan reaksi sintesis senyawa (E)-2'-hidroksi-2-bromo-4,5-dimetoksikalkon

Hasil spektra FTIR menunjukkan adanya perubahan puncak serapan gugus $\mathrm{C}=\mathrm{O}$ karbonil pada 2-bromo-4,5-dimetoksibenzaldehida dari bilangan gelombang $1666 \mathrm{~cm}^{-1}$ menjadi $1635 \mathrm{~cm}^{-1}$ pada produk turunan kalkon. Perubahan terjadi akibat ikatan $\mathrm{C}=\mathrm{O}$ pada turunan kalkon lebih lemah dibandingkan dengan ikatan $\mathrm{C}=\mathrm{O}$ pada 2-bromo-4,5dimetoksibenzaldehida. Choudhari dkk (2011) menyatakan bahwa karakteristik gugus $\mathrm{C}=\mathrm{O}$ dari senyawa turunan kalkon muncul pada bilangan gelombang $1630-1660 \mathrm{~cm}^{-1}$.

Munculnya serapan pada bilangan gelombang $972 \mathrm{~cm}^{-1}$ sebagai vibrasi tekuk dari gugus $\mathrm{C}-\mathrm{H}$ alkena trans yang menjadi indikasi telah terbentuknya senyawa turunan kalkon. Hal ini menunjukkan bahwa gugus aldehida telah berubah menjadi alkena setelah terjadi adisi keton dan eliminasi $\mathrm{H}_{2} \mathrm{O}$. Hilangnya puncak pada bilangan gelombang $2777 \mathrm{~cm}^{-1}$ yang merupakan karakter gugus aldehida memperkuat telah terbentuknya senyawa turunan kalkon. Gugus bromo muncul pada bilangan gelombang $663 \mathrm{~cm}^{-1}$ dan gugus hidroksil pada $3441 \mathrm{~cm}^{-1}$. Hasil interpretasi spektra FTIR disajikan pada tabel berikut. 
Tabel 1. Hasil interpretasi spektra FTIR senyawa (E)-2'-hidroksi-2-bromo-4,5-dimetoksikalkon

\begin{tabular}{cc}
\hline Bilangan gelombang $\left(\mathrm{cm}^{-1}\right)$ & Gugus fungsi \\
\hline 3441 & $\mathrm{OH}$ \\
3086 & $\mathrm{C}_{\mathrm{sp} 2}-\mathrm{H}$ \\
1635 & $\mathrm{C}=\mathrm{O}$ \\
1504 dan 1573 & $\mathrm{C}=\mathrm{C}$ aromatic \\
1026 & $\mathrm{C}-\mathrm{O}-\mathrm{C}$ \\
972 & $\mathrm{C}_{\mathrm{sp} 2}-\mathrm{H}$ olefin trans \\
663 & $\mathrm{C}-\mathrm{Br}$ \\
\hline
\end{tabular}

Hasil analisis MS-direct menunjukkan bahwa senyawa (E)-2'-hidroksi-2-bromo4,5-dimetoksikalkon memiliki ion molekuler $\left(\mathrm{M}^{+}\right) 362$ dan 364 yang sesuai dengan berat molekul senyawa target. Kemurnian senyawa dianalisis dengan KLT-scanner yang ditunjukkan dengan terlihatnya noda dari senyawa hasil sintesis dengan persentase sebesar $100 \%$. Hasil analisis ${ }^{1} \mathrm{H}-\mathrm{NMR}$ menunjukkan adanya 11 jenis proton yang sesuai dengan senyawa target. Karakteristik senyawa (E)-2'-hidroksi-2-bromo-4,5-dimetoksikalkon ditunjukkan pada proton 7 dan 10 yang merupakan puncak $\mathrm{H} \alpha$ dan $\mathrm{H} \beta$ dengan pergeseran kimia $(\delta)$ 7,45 ppm dan 8,41 ppm serta konstanta kopling $(J)$ sebesar 15,55 dan 15,55 Hz. Menurut Silverstein dkk (2005) konstanta kopling $(J)$ tersebut menunjukkan adanya alkena trans dari gugus $\alpha, \beta$-karbonil tak jenuh.

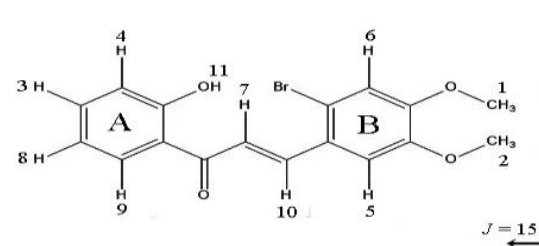

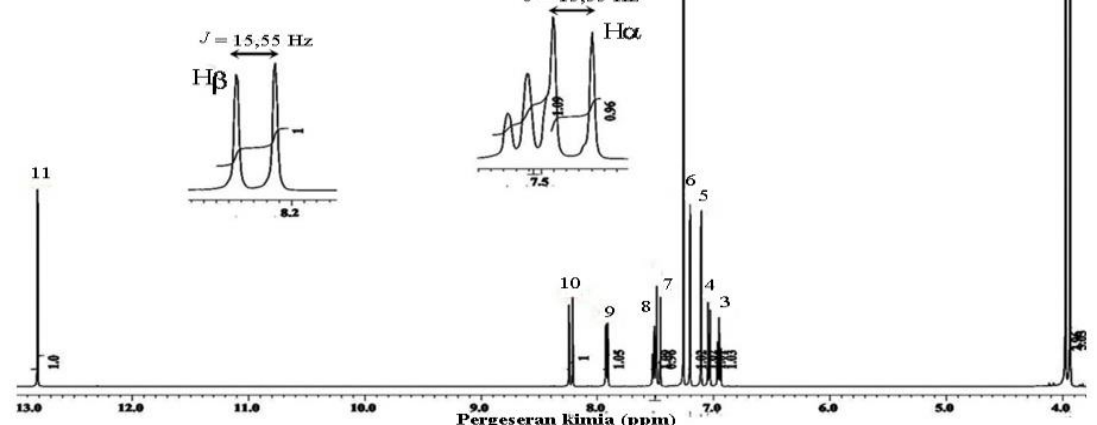

Gambar 5. Spektra ${ }^{1}$ H-NMR senyawa (E)-2'-hidroksi-2-bromo-4,5-dimetoksikalkon

Pergeseran kimia proton $\mathrm{H} \beta$ muncul pada daerah yang lebih downfield jika dibandingkan dengan proton $\mathrm{H} \alpha$ akibat adanya polarisasi ikatan rangkap $\mathrm{C}=\mathrm{C}$ yang disebabkan oleh gugus karbonil sehingga membuat densitas elektron pada posisi $\alpha$ lebih besar dibandingkan dengan posisi $\beta$ (Shorey dkk., 2013). Karakteristik senyawa turunan kalkon memiliki serapan proton alkena dengan konstanta kopling (J) sebesar 15,76 Hz yang menunjukkan bahwa senyawa turunan kalkon yang terbentuk didominasi oleh isomer trans (Jarag dkk., 2011). Hasil interpretasi spektra ${ }^{1}$ H-NMR disajikan pada tabel berikut.

Tabel 2. Hasil analisis ${ }^{1}$ H-NMR senyawa (E)-2'-hidroksi-2-bromo-4,5-dimetoksikalkon 

Bakteri Bacillus subtilis dan Escherichia coli

\begin{tabular}{ccccc}
\hline Puncak & $\begin{array}{c}\text { Pergeseran kimia } \\
(\delta, \mathrm{ppm})\end{array}$ & Kenampakan & $\begin{array}{c}\text { Tetapan } \\
\text { kopling }(J, \mathrm{~Hz})\end{array}$ & Jumlah dan tipe proton \\
\hline 1 & 3,93 & Singlet & & $3,-\mathrm{OCH}_{3}$ \\
2 & 3,97 & Singlet & & $3,-\mathrm{OCH}_{3}$ \\
3 & 6,95 & Triplet & 7,75 dan 7,8 & $1,-\mathrm{Ar}_{\mathrm{A}}-\mathrm{H}$ \\
4 & 7,03 & Doublet & 8,4 & $1,-\mathrm{Ar}_{\mathrm{A}}-\mathrm{H}$ \\
5 & 7,10 & Singlet & & $1,-\mathrm{Ar}_{\mathrm{B}}-\mathrm{H}$ \\
6 & 7,20 & Singlet & & $1,-\mathrm{Ar}_{\mathrm{B}}-\mathrm{H}$ \\
7 & 7,45 & Doublet & 15,55 & $1,=\mathrm{CH}$ \\
8 & 7,49 & Triplet & 7,8 dan 7,8 & $1,-\mathrm{Ar}_{\mathrm{A}}-\mathrm{H}$ \\
9 & 7,91 & Doublet & 7,8 & $1,-\mathrm{Ar}_{\mathrm{A}}-\mathrm{H}$ \\
10 & 8,21 & Doublet & 15,55 & $1,=\mathrm{CH}_{\beta}$ \\
11 & 12,81 & Singlet & & $1,-\mathrm{Ar}_{\mathrm{A}}-\mathrm{OH}$ \\
\hline
\end{tabular}

Hasil analisis ${ }^{13} \mathrm{C}$-NMR menunjukkan bahwa jumlah karbon yang terbentuk sesuai dengan jumlah karbon pada senyawa target sebanyak 17 karbon. Karakteristik terbentuknya senyawa target terlihat dari puncak 7 yang menunjukkan $\mathrm{C} \alpha$ dengan pergeseran kimia $(\delta) 118,95$ ppm serta puncak 13 sebagai $\mathrm{C} \beta$ dengan pergesaran kimia ( $\delta) 143,96 \mathrm{ppm}$.<smiles>CCOc1cc(Br)c(/C=C/[Te](=O)c2ccccc2O)cc1OC</smiles>

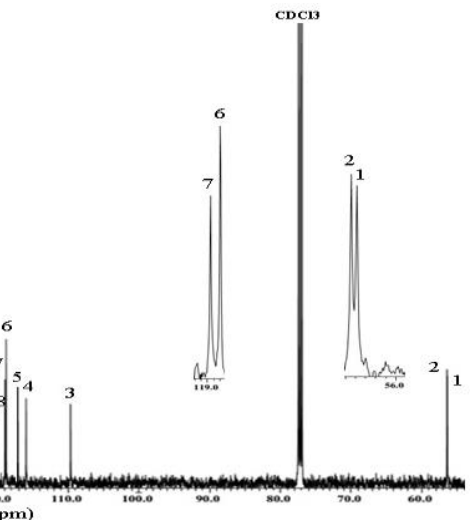

Gambar 6. Spektra ${ }^{13}$ C-NMR senyawa (E)-2'-hidroksi-2-bromo-4,5-dimetoksikalkon

Berkurangnya kerapatan elektron pada $\mathrm{C} \beta$ dibandingkan dengan $\mathrm{C} \alpha$ akibat dari elektron pada ikatan rangkap tertarik sangat kuat oleh karbonil melalui resonansi sehingga $\mathrm{C} \alpha$ sangat terlindungi dan berada di daerah upfield. Hasil interpretasi spektra ${ }^{13} \mathrm{C}-\mathrm{NMR}$ disajikan pada tabel berikut.

Tabel 3. Hasil analisis ${ }^{13} \mathrm{C}-\mathrm{NMR}$ senyawa (E)-2'-hidroksi-2-bromo-4,5-dimetoksikalkon

\begin{tabular}{ccc}
\hline Puncak & Pergeseran Kimia $(\delta, \mathrm{ppm})$ & Jumlah dan Tipe Karbon \\
\hline 1 & 56,38 & $1,-\mathrm{OCH}_{3}$ \\
2 & 56,44 & $1,-\mathrm{OCH}_{3}$ \\
3 & 109,67 & $1,-\mathrm{C}_{\mathrm{Ar}-\mathrm{B}-\mathrm{Br}}$ \\
4 & 115,97 & $1,-\mathrm{C}_{\mathrm{Ar}-\mathrm{B}}$ \\
5 & 117,85 & $1,-\mathrm{C}_{\mathrm{Ar}-\mathrm{A}}$ \\
6 & 118,79 & $1,-\mathrm{C}_{\mathrm{Ar}-\mathrm{B}}$ \\
7 & 118,95 & $1,=\mathrm{C}_{\alpha}-\mathrm{H}$ \\
8 & 120,08 & $1,-\mathrm{C} \mathrm{Ar}-\mathrm{A}$ \\
9 & 120,52 & $1,-\mathrm{C}_{\mathrm{Ar}-\mathrm{A}}$ \\
10 & 126,65 & $1,-\mathrm{C}_{\mathrm{Ar}-\mathrm{B}}$ \\
11 & 129,76 & $1,-\mathrm{C}_{\mathrm{Ar}-\mathrm{A}}$ \\
12 & 136,52 & $1,-\mathrm{C}_{\mathrm{Ar}-\mathrm{A}}$ \\
\hline
\end{tabular}




\begin{tabular}{lcc}
\hline 13 & 143,96 & $1,=\mathrm{C}_{\beta}-\mathrm{H}$ \\
14 & 148,83 & $1,-\mathrm{C}_{\mathrm{Ar}-\mathrm{B}-\mathrm{OCH}}$ \\
15 & 152,00 & $1,-\mathrm{C}_{\mathrm{Ar}-\mathrm{B}}-\mathrm{OCH}_{3}$ \\
16 & 163,71 & $1,-\mathrm{C}_{\mathrm{Ar}-\mathrm{A}-\mathrm{OH}}$ \\
17 & 193,51 & $1,-\mathrm{C}=\mathrm{O}$ \\
\hline
\end{tabular}

\section{Uji Aktivitas Antibakteri}

Uji aktivitas antibakteri dilakukan dengan metode difusi cakram (sumuran). Metode ini didasarkan pada kemampuan dari senyawa uji untuk menghasilkan jari-jari zona penghambatan di sekeliling sumur uji terhadap bakteri yang digunakan sebagai penguji (Nurainy dkk., 2008). Pada uji antibakteri digunakan kontrol positif berupa 4-isopropil-3metilfenol (O-cymen) $1 \%$ yang umumnya memiliki aktivitas dalam menghambat bakteri Bacillus substilis dan Escherichia coli. Hasil uji antibakteri senyawa (E)- 2'-hidroksi-2bromo-4,5-dimetoksikalkon ditunjukkan pada tabel berikut.

Tabel 4. Daya hambat senyawa (E)- 2'-hidroksi-2-bromo-4,5-dimetoksikalkon terhadap bakteri uji.

\begin{tabular}{ccc}
\hline Konsentrasi sampel & \multicolumn{2}{c}{ Diameter daya Hambat } \\
\cline { 2 - 3 } $20 \%$ & Bacillus substillis & Escherichia coli \\
$10 \%$ & 19,7 & 17,7 \\
$5 \%$ & 17 & 16 \\
$1 \%$ & 15 & 15,3 \\
Kontrol Positif $1 \%$ & 15 & 13,3 \\
\hline
\end{tabular}

Hasil uji daya hambat bakteri terhadap senyawa (E)- 2'-hidroksi-2-bromo-4,5dimetoksikalkon menunjukkan adanya aktivitas sebagai antibakteri terhadap bakteri Bacillus substillis dan Escherichia coli. Menurut Davis dan Stout (1971) terdapat empat tingkatan klasifikasi hambatan pertumbuhan bakteri meliputi zona hambat lebih dari 20 $\mathrm{mm}$ dikatakan sangat kuat, zona hambat 10-20 mm dikatakan kuat, zona hambat 5-10 mm dikatakan sedang, dan zona hambat kurang dari $5 \mathrm{~mm}$ dikatakan lemah. Berdasarkan hasil uji daya hambat menunjukkan bahwa senyawa (E)- 2'-hidroksi-2-bromo-4,5dimetoksikalkon tergolong memiliki aktivitas kuat dalam menghambat pertumbuhan bakteri Bacillus substillis sebesar 19,7 mm pada konsentrasi 20\% dan bakteri Escherichia coli sebesar $17,7 \mathrm{~mm}$ pada konsentrasi $20 \%$.

Aktivitas daya hambat senyawa (E)-2'-hidroksi-2-bromo-4,5-dimetoksikalkon terhadap bakteri Bacillus substillis lebih bedar dibandingkan pada bakteri Escherichia coli. Perbedaan ini didasarkan pada kemampuan penembusan dinding sel bakteri. Bakteri Bacillus substillis merupakan bakteri gram positif yang memiliki dinding sel terdiri dari lapisan peptidoglikan dengan polimer-polimer asam terikat yang melekat padanya. Sedangkan bakteri Escherichia coli merupakan bakteri gram negatif yang memiliki dinding sel berlapir/multi layer dan kompleks dengan membran terluar yang dapat bekerja sebagai baries berbagai senyawa yang termasuk diantaranya senyawa antibakteri. 


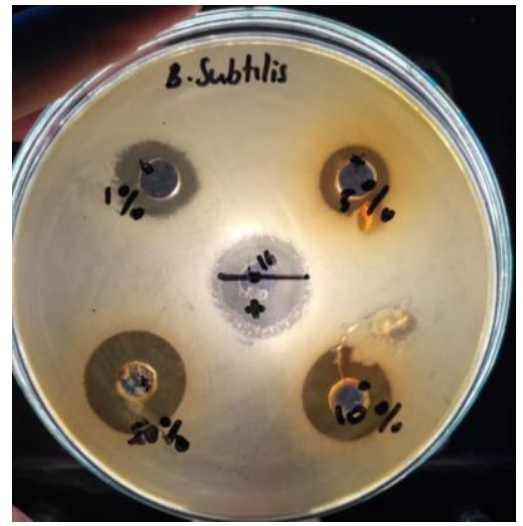

(a)

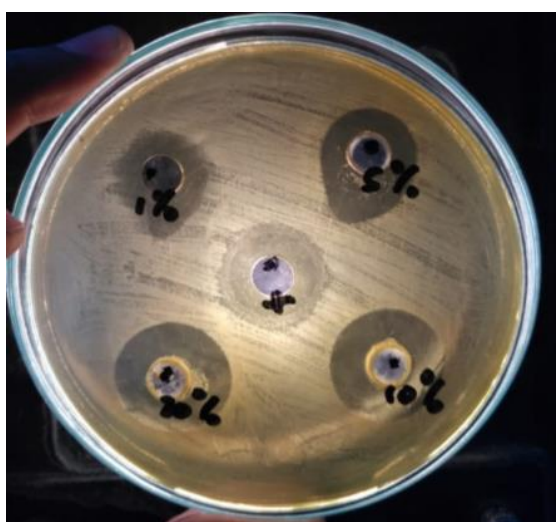

(b)

Gambar 7. Uji daya hambat terhadap bakteri (a) Bacillus substillis dan (b) Escherichia coli

Lapisan peptidoglikan pada bakteri gram negatif lebih tipis dibandingkan pada bakteri gram positif dan dikelilingi oleh suatu membran luar yang terdiri dari lipopolisakarida dan lipoprotein. Menurut Prasad dkk (2008) komponen lipopolisakarida dari dinding sel gram negatif merupakan molekul endotoksin yang memberikan sumbangan pada patogenesis bakteri. Oleh karena itu, aktivitas penghambatan pada bakteri gram positif lebih baik daripada bakteri gram negatif.

Senyawa (E)-2'-hidroksi-2-bromo-4,5-dimetoksikalkon memiliki gugus keton $\alpha \beta$ tak jenuh yang bertindak sebagai antibakteri (Lahtchev dkk., 2008). Aktivitas antibakteri senyawa turunan kalkon bergantung pada jenis substituen yang terikat pada kedua cincin aromatiknya. Adanya gugus bromida pada senyawa (E)-2'-hidroksi-2-bromo-4,5dimetoksikalkon menyebabkan senyawa tersebut memiliki aktivitas yang cukup baik dalam menghambat pertumbuhan bakteri. Jika dibandingkan antara kontrol positif 4isopropil-3-metilfenol (O-cymen) dan senyawa hasil sintesis pada konsentrasi yang sama yaitu $1 \%$ terlihat kedua senyawa memiliki aktivitas yang hampir sama dalam menghambat bakteri Bacillus substillis dan Escherichia coli. Daya hambat kontrol positif pada bakteri Bacillus substillis sekitar 15,3 mm sedangkan pada senyawa hasil sintesis sekitar $15 \mathrm{~mm}$. Daya hambat kontrol positif pada bakteri Escherichia coli sekitar $13 \mathrm{~mm}$ sedangkan pada senyawa hasil sintesis $13,3 \mathrm{~mm}$. Oleh karena itu, dapat disimpulkan bahwa senyawa (E)2'-hidroksi-2-bromo-4,5-dimetoksikalkon hasil sintesis memiliki aktivitas sebagai antibakteri.

\section{PENUTUP}

Senyawa (E)-2'-hidroksi-2-bromo-4,5-dimetoksikalkon telah berhasil disintesis dari 2-bromo-4,5-dimetoksibenzaldehida dan 2-hidroksiasetofenon dengan menggunakan katalis basa $\mathrm{NaOH}$ menghasilkan rendemen sebesar 78,45\%. Senyawa (E)-2'-hidroksi-2bromo-4,5-dimetoksikalkon memiliki potensi sebagai antibakteri pada bakteri Bacillus substillis dan Escherichia coli. Aktivitas tertinggi ditunjukkan pada konsentrasi $20 \%$ untuk kedua bakteri tersebut. Semakin tinggi konsentrasi senyawa maka semakin tinggi daya hambat senyawa terhadap bakteri. Zona hambat senyawa (E)-2'-hidroksi-2-bromo-4,5dimetoksikalkon terhadap bakteri Bacillus substillis lebih baik dibandingkan pada bakteri Escherichia coli. Zona hambat senyawa tersebut pada bakteri Bacillus substillis dan Escherichia coli dengan konsentrasi $20 \%$ berturut-turut sebesar 19,7 nm dan 17,7 nm. 


\section{DAFTAR PUSTAKA}

Achanta, G,. Modzelewska, A., Feng, L,. Khan, S.R,. \& Huang, P., 2006, boronic chalcone derivative exhibits potent anticancer activity through inhibition of the proteasome, Molecular prarmacol, 70: 426-433.

Bhuiyan, M.M.H., Hossain, M.I., Mahmud, M.M., \& Amin, MA., 2011, Microwaveassisted efficient synthesis of chalcones as probes for antimicrobial activities, Chemistry journal, 1(1): 21-28.

Choudharya, A.N., and Juyal, V., 2011, Synthesis of chalcone and their derivatives as antimicrobial agents, Int. J. Pharm. Pharm. Sci., 3(3): 125-128.

Davis, W.W., and Stout, T.R., 1971, disc plate methods of microbiological antibiotic assay, App. Microbioll., 22(4): 659-665.

Jarag, K. J., Pinjari, D.V., Pandit, A.B., \& Shankarling, G.S., 2011, Synthesis of chalcone (3-(4-fluorophenyl)-1-(4-methoxyphenyl)-prop-2-en-1-one): advantage of sonochemical method over conventional method, Ultrason. Sonochem., 18: 617-623.

Jasril, Teruna, H.Y., Zamri, A., Alfatos, D., Yuslinda, E., \& Nurulita, Y., 2012, sintesis dan uji antibakteri senyawa bromo kalkon piridin, Jurnal Natur Indonesia, 14(3):172-175.

Kim, Y.H., Kim, J., Park, H., \& Kim, H.P., 2007, Anti-inflammatory activity of the synthetic chalcone derivative: inhibition of inducible nitric oxide synthase-catalyzed nitric oxide production from lipopoly saccharide-treated raw 264.7 cells, Biol. Pharm. Bull., 30(8): 1450-1455.

Lahtchev, K.L., Batovska, D.I., Parushev, St.P., Ubiyvovk, V.M., \& Sibirny, A.A., 2008, Antifungal activity of chalcones: a mechanistic study using various yeast strains, European journal of medicinal chemistry, 43: 2220-2228.

Normark, B.H \& Normark, S., 2002, Evolution and spread of antibiotic resistance, J Intern Med., 252(2): 91-106.

Nugraha, H.P., 2015, Sintesis dan uji aktivitas antibakteri senyawa pirazolina berbahan dasar 3-metoksi-4-hidroksibenzaldehida (vanilin) dan 4-metoksibenzaldehida (panisaldehida), Skripsi, FMIPA Universitas Gadjah Mada.

Nurainy, F., Rizal, S., \& Yudiantotro, 2008, The effect of chitosan concentration on the antibacterial activity with gel diffusion/well method, Jurnal Teknologi Industri dan Hasil Pertanian, 13(2): 117-125.

Prasad, Y.R., Rao, A.L., \& Rambabu, R., 2008, Synthesis and antimicrobial activity of some chalcone derivatives, E-Journal of Chemistry, 5(3): 461-466. 
Prasad, Y.R., Kumar, P.R., Deepti, C.A., \& Ramana, M.V., 2006, Synthesis and antimicrobial activity of some novel chalcones of 2-hydroxy-1- acetonapthoneand 3-acetyl coumarin, E-Journal of Chemistry. 3(13): 236-241.

Shorey, S., Choudhary, P. C., and Intodia, K., 2013, Microwave irradiation synthesis of various substituted chalcones using various heterogeneous catalysts under solventfree conditions and their biological studies, Chem. Sci. Trans., 2(2), 343-348.

Silverstein, R. M., Webster, F. X., and Kiemle, D. J., 2005, Spectrometric Identification of Organic Compound, John Wiley \& Son Inc., New York.

Wu, J.H., Wang, X.H., Yi, Y.H., \& Lee, K.H., 2003, Anti-aids agents 54 a potent anti-hiv chalcone and flavonoids from genus desmos, Bioorg. Med. Chem. Lett., 13(10): 1813-1815. 